Fauzan, Helmi, Zulkifli Harza, Sri Oktavia | Capacity Building and Market

Intervention for Refugees: A Study of Current and Future Direction towards

Sustainable Refugee Management

Article

\title{
Capacity Building and Market Intervention for Refugees: A Study of Current and Future Direction towards Sustainable Refugee Management
}

Fauzan, Helmi, Zulkifli Harza, Sri Oktavia

${ }^{I}$ Development Studies, Universitas Andalas, Padang, Indonesia

${ }^{2}$ Development Studies, Universitas Andalas, Padang, Indonesia

${ }^{3}$ International Relation Department, Universitas Andalas, Padang, Indonesia

${ }^{4}$ Law Department, Universitas Andalas, Padang, Indonesia

\section{SUBMISSION TRACK}

$\begin{array}{ll}\text { Recieved } & : \text { 15 February } 2020 \\ \text { Final Revision } & : \text { 25 April } 2020 \\ \text { Available Online } & : \text { 30 May } 2020\end{array}$

KEYWORD

Sustainable refugee management, capacity building, labor opportunities, UNHCR

\section{KATA KUNCI}

Pengelolaan pengungsi berkelanjutan, pembangunan kapasitas, kesempatan kerja, UNHCR.

\section{CORRESSPONDENCE}

E-mail: fauzan1831622003@ student.unand.ac.id

\section{A B S T RA C T}

The increasing population of Refugees globally has challenged states and the UNHCR nowadays. States face a difficulty in managing the arrivals of refugees, while the UN Agency for refugees has a limitation in the resettlement purposes. This research will explore the current management of refugees by states and the UNHCR and future direction towards sustainable managing refugees through capacity building and market intervention. The methodology used is a quantitative study through a statistical descriptive analysis from secondary sources. The result shows that currently, states under the convention and Protocol of refugees tend to refuse the arrivals of refugees due to the security and sovereignty issues. In the meantime, the UNHCR faces a challenge in resettlement process, in which the necessity for resettlement has increased while the state's quota has reduced. As a result, refugees are required to stay longer in transiting countries.

\section{A B S T R A K}

Jumlah pengungsi didunia saat ini semakin meningkat yang menjadi tantangan tersendiri dalam penanganannya. Di satu sisi, negara memiliki keterbatasan dalam menerima kehadiran pengungsi, sementara di sisi yang lain, UNHCR mengalami kesulitan dalam mengirimkan pengungsi ke negara ketiga. Tujuan penelitian ini adalah untuk mengeksplorasi penanganan pengungsi oleh negara dan UNHCR saat ini serta arah ke depan dalam penanganan pengungsi melalui kemitraan dengan sektor swasta untuk meningkatkan kapasitas dan intervensi perluasan pasar bagi pengungsi. Metode yang digunakan adalah kuantitatif melalui analisis deskripsi statistik dari sumber sekunder dan tinjauan literatur. Hasil penelitian menunjukkan bahwa pada saat ini negara tujuan kesulitan dalam menangani permasalahan pengungsi dengan alasan keamanan dan kedaulatan. Sementara itu, UNHCR mengalami tantangan dalam penempatan pengungsi dinegara ketiga dimana jumlah permintaan untuk resettlement meningkat sementara jumlah kuota penerimaan pengungsi berkurang. Hal ini menyebabkan pengungsi harus tinggal lebih lama di negara transit 
Fauzan, Helmi, Zulkifli Harza, Sri Oktavia | Capacity Building and Market Intervention for Refugees: A Study of Current and Future Direction towards Sustainable Refugee Management

\section{Introduction}

The mobility of refugees has become a phenomenon worldwide recently, not only for destination countries but also for home and transit countries. As part of the migrant movement, refugees have become the world's attention particularly after the initiation of the Global Compact of Migration and Refugees in 2018. To provide safe and responsible mobility of people, members of the United Nations have also agreed to include the issue of refugee and migration in the Sustainable Development Goals (SDGs) agenda, to be achieved in $2030{ }^{1}$. Each member is requested to achieve these goals and must be stated in each country of strategic planning for ensuring that international migrants are moveable safely and orderly responsible ${ }^{2}$.

In addition, the increasing mobility of refugees has also recorded in the increasing number of the global refugee population. As shown in Table 1 below, the population of the refugee has increased to 19.9 million in 2017, where Europe and Asia and Pacific regions have been identified as the second and third largest refugee population after the Africa region. In Europe, Turkey hosted more than three million refugees from Syria to avoid conflict and war while in Asia and Pacific, the number of refugees is largely from Myanmar known as Rohingya in avoidance of persecution ${ }^{3}$.

Table 1: Refugee Population under UNHCR mandate (UNHCR, 2018a)

\begin{tabular}{lcclc}
\hline $\begin{array}{l}\text { UNHCR } \\
\text { regions }\end{array}$ & $\mathbf{2 0 1 6}$ & $\mathbf{2 0 1 7}$ & Change & $\%$ \\
\hline Africa & 5.135 .100 & 6.268 .200 & 1.133 .100 & 22.1 \\
\hline
\end{tabular}

1 IOM, "Migration in the 2030 Agenda"; ODI, "Migration and the 2030 Agenda for Sustainable Development."

2 ESCAP, "UN Economic and Social Council: International Migration, the 2030 Agenda for Sustainable Development and the Global Compact for Safe, Orderly and Regular Migration."

${ }^{3}$ UNHCR, "Forced Displacement in 2017."

\begin{tabular}{lrrrr}
\hline America & 682.700 & 644.200 & -38.500 & -5.6 \\
\hline $\begin{array}{l}\text { Asia and } \\
\text { Pacific }\end{array}$ & 3.477 .800 & 4.209 .700 & 731.900 & 21.0 \\
\hline Europe & 5.200 .200 & 6.114 .300 & 914.100 & 17.6 \\
\hline $\begin{array}{l}\text { Turkey } \\
\text { Middle }\end{array}$ & 2.869 .400 & 3.480 .300 & 610.900 & 21.3 \\
\hline East & 2.679 .500 & 2.704 .900 & 25.400 & 0.9 \\
\hline \multicolumn{1}{c}{ Total } & 17.175 .300 & 19.941 .000 & 2.766 .00 & 16.1 \\
\hline
\end{tabular}

This phenomenon has underestimated the importance of humanity and livelihood opportunities for refugees to seek protection for their future life. Indeed, refugees are obliged for international protection and universal human rights that need to be protected and fulfilled according to international laws ${ }^{4}$.

In the meantime, the current refugee management by states still focuses on the security issue and immigration procedures through tightening borders and patrols. Although states are authorized to manage refugees through local integration as stated in the Refugee Convention in 1951 and its Protocol in 1967, they seem reluctant to receive new arrivals of refugees. Partly it is because of the issue of sovereignty and economic activities as well as political stability in their territories. Furthermore, some people in destination countries also assumed that the existence of refugees could endanger their culture and economic activity and further could create a terrorism activity in their countries ${ }^{5}$.

For states who are not a part of the Convention of Refugees, the management of refugees is carried out by the United Nations High Commissioner for Refugee (UNHCR). The office has a key role in repatriation, local integration, and resettlement of

\footnotetext{
${ }^{4}$ Costello, "Refugees and (Other) Migrants: Will the Global Compacts Ensure Safe Flight and Onward Mobility for Refugees?"

5 Jones et al., "Interventions on the State of Sovereignty at the Border."
} 
Fauzan, Helmi, Zulkifli Harza, Sri Oktavia | Capacity Building and Market Intervention for Refugees: A Study of Current and Future Direction towards Sustainable Refugee Management

refugees ${ }^{6}$. Repatriation or returning back refugees to their origin countries are obviously not a proper action since they are in an immediate need for protection while their countries are still in conflict or in an unsafe condition. In addition, local integration might not likely be a potential outcome since most transiting countries are in developing countries that are lack of rules and regulation in the international protection of refugees through integration. Thus, one promising solution for the refugee is likely through the process of resettlement to third countries. Unfortunately, the quota for resettlement has decreased by $50 \%$ in 2017, and the successful resettlement process each year is less than 100.000 from nearly 20 million refugees globally. ${ }^{7}$. While waiting for the resettlement process, refugees are required to stay in transiting countries until they are finally replaced this could take a long period of time.

Relying on the challenges of the states and the limitation of resettlement faced by the UNHCR, it seems necessary to have a future direction towards managing refugees sustainably. This is possible since the refugee is a very complex issue, touching not only economic but also social and political intervention. One alternative approach is carried out by providing skill development for refugees and opportunities to enter market places for the future livelihood of refugees. Market intervention and capacity building are perceived as part of sustainable refugee management ${ }^{8}$. In relation to market opportunities, it seems important to have a partnership with private sectors since businesses are closely related to providing job accessibility and opportunities. Moreover, the partnership has also been stated as one of the specific goals of SDGs to

\footnotetext{
${ }^{6}$ Susetyo, Fitria, and Asyhari, Rohingya: Stateless People and Nowhere To Go.

${ }^{7}$ UNHCR, "Glob. Appeal 2019 Updat."

${ }^{8}$ ICID, “TOWARDS SUSTAINABLE MIGRATION: Interventions in Countries of Origin."
}

be achieved in 2030 along with other global initiatives, since refugee is a global and complex problem. Collaboration and cooperation with business entities will significantly increase the opportunities for refugees entering the labor market as well as equipping them with relevant skill development.

Previous study has shown that business can contribute to the solution of migrants by providing training and skills for their future . The experience of companies in refugee management had been shown by the European countries in dealing with the influx of Syrian refugees in 2015, particularly in Germany. In the Asia Pacific, the Bali Declaration had also welcomed business actors to collaborate with states to deal with the issue of human trafficking, people smuggling and other transnational crimes in the region ${ }^{10}$. The same experience was also shown by Australia when the country worked with private sectors to provide business flows for migrants, incentives and strong union monitoring to avoid cheap labor for migrants (Warshall, 2002).

Specifically, the UNHCR has worked with private sectors to support self-reliance of refugees with the core principle in human rights knowledge while advocating the ethical and decent works in company supply chains $^{1112}$. This research will look at such collaboration but focus more on capacity building and market intervention for the future of refugee's self-reliance.

The structure of this research is designed as follows. Firstly, following the

\footnotetext{
${ }^{9}$ Horowitz, "Chobani CEO Hamdi Ulukaya Has a Message on Refugees Every Business Needs to Hear." 10 RSO Bali Process, "Declaration of the Seventh Ministerial Conference of the Bali Process on People Smuggling, Trafficking in Persons and Related Transnational Crime (Bali Process)."

11 Mehan, "From Care and Maintenance to SelfReliance: Sustainable Business Model Connecting Malian Refugee Artisans to Swiss Markets Using Public-Private Partnerships."

12 Ibid.
} 
Fauzan, Helmi, Zulkifli Harza, Sri Oktavia | Capacity Building and Market Intervention for Refugees: A Study of Current and Future Direction towards Sustainable Refugee Management

introduction is the explanation of research methodology, including data gathering and analysis. Afterwards, the result is discussed including the current management of refugees from state and the UNHCR perspectives. In the discussion section, the future direction of sustainable refugee management will be deeply analyzed, which focuses on capacity building and market intervention through the involvement of private sectors. To conclude, this paper will provide a brief summary and some limitations in the future agendas of the issue to be explored further.

\section{Research Method}

The research methodology is an important step in seeking answers for the problems arises in any research since it draws a general road map of a future research agenda. In addition, the method will lead the researcher to consider a specific approach in designing the research method through data collection and analysis. Traditionally, research methodologies have been classified into two distinctive methods, qualitative and quantitative leading to dividing two large groups of researchers in a particular field of social studies ${ }^{13}$. This paper will employ the quantitative study, with specific samples and statistical data to gain a deep understanding of the topic.

In collecting data, this paper focuses on statistical data as secondary sources and literature reviews on relevant subjects. These include the refugee management statistics, state authorities, rules and global convention as empirical data related to refugee issues. In regards to state and UNHCR responsibility in managing refugees, data in numbers and statistics are reviewed in order to provide a general picture of refugee management. Some data include the population of refugees

13 Onwuegbuzie and Leech, "On Becoming a Pragmatic Researcher: The Importance of Combining Quantitative and Qualitative Research Methodologies." globally, the number of refugees in different states defined at regional levels, resettlement quotas and state allocation for placement of refugees. In addition, data on SDGs particularly the goal of 17 , which is the partnership, will be analyzed deeply together with other international rules and Conventions. These include data from Global Compact for Refugee, Global Compact for Migration and ILO statistical documents for future management of refugees.

In data analysis, this paper employs a statistical descriptive analysis. It draws data upon tables, graphs, circular diagrams and figures to search a connection and comparison to hypothesize the findings ${ }^{14}$. These include data and information between the resettlement necessity and the quota of receiving resettled refugees by states. On one side, the UNHCR needs to resettle a large number of refugees but on the other side, states tend to reduce the number of resettlement quotas resulting in uncertainty and long periods of waiting for refugees in transit countries. In addition, the experience of some States in managing refugees at the regional level is also explored to strengthen a hypothesize that states have faced difficulties in finding a durable solution for refugees.

\section{Result and Discussion}

Management of refugees originally could be carried out by two actors, states and the UNHCR. States that have ratified their membership to become part of the 1951 Refugee and Its Protocol in 1967 are given authorities themselves to manage the arrival of refugees into local integration. Meanwhile, the UNHCR has a key role in organizing refugee management particularly in states who are not a party of the above Convention. This includes Repatriation, local integration, and resettlement to third

\footnotetext{
14 Sugiyono, Metode Penelitian Kombinasi (Mixed Methods).
} 
Fauzan, Helmi, Zulkifli Harza, Sri Oktavia | Capacity Building and Market Intervention for Refugees: A Study of Current and Future Direction towards Sustainable Refugee Management

countries $^{15}$. The management of refugees by states and the UNHCR will be discussed deeply below.

\section{Current refugee management by states}

The role of states in managing refugees has originally been started since decades ago after the establishment of the 1951 Refugee Convention, to have the protection of refugees from Europe in fleeing away from war. The refugee convention is basically a necessity to provide standard treatment for refugees after World War (WW) II where a large number of refugees, particularly in Europe have challenged international communities $^{16}$. However, the need for refugee management continued after WW II and includes states other than European countries. To deal with this situation, there was an issuance of Refugee Protocols in 1967 where states involved are not only in the EU region but also include those outside the EU. Furthermore, the Protocol has also excluded temporal and geographical areas, meaning that refugees that happened before and after January 1, 1951, are also considered as refugees and states are required to provide protection for refugees ${ }^{17}$.

Unfortunately, many states, particularly in Europe, have found difficulties in managing new arrivals of refugees from Syria in large numbers since 2015. Although some leaders express the need for extraordinary effort to help refugees and asked humanity solidarity to help refugees, they tend not to have refugees in their areas and leave them in other transiting countries. They also tend to focus on the security issue and border tightening not allowing the arrival of refugees inside the

\footnotetext{
15 Susetyo, Fitria, and Asyhari, Rohingya: Stateless People and Nowhere To Go.

16 Weis, "The 1951 Refugee Convention: The Travaux Preparatoires Analysed with a Commentary." ${ }^{17}$ Ibid.
}

countries ${ }^{18}$. One of the main reasons behind those policies is sovereignty, in which the influx of refugees could harm their culture, economy and social benefit of their local population $^{19}$. Furthermore, some people in destination countries also assumed that the existence of international migrants will endanger their culture and economic activity and further could create a terrorism activity in their countries ${ }^{20}$.

Furthermore, there seems no comprehensive solution from the EU to deal with the increasing number of refugees in Europe. As a result, every member takes a different approach to deal with a large number of refugees. Hungary, for example, built a high and thick wall in its border to refuse the coming of refugees, and thus, refugees will not be allowed to enter the country. A similar approach is also implemented by the Czech Republic where the country applies a tight and secured immigration rule, in which detaining is conducted for illegal migrants and refugees from 40 to 90 days ${ }^{21}$. This condition creates uncertainty for refugees since they are not able to enter destination countries. There are also a lot of issues of violation of human rights and attacks on civilians in the border territory ${ }^{22}$.

A different approach was shown by Germany to receive Syrian refugees in 2015. Germany has been well known for its welcoming culture when accepting more

\footnotetext{
18 Frelick, Kysel, and Podkul, "The Impact of Externalization of Migration Controls on the Rights of Asylum Seekers and Other Migrants."

${ }^{19}$ Young, Loebach, and Korinek, "Building Walls or Opening Borders? Global Immigration Policy Attitudes across Economic, Cultural and Human Security Contexts 2 ? "

20 Jones et al., "Interventions on the State of Sovereignty at the Border."

21 Grigonis, "EU in the Face of Migrant Crisis : Reasons for Ineffective Human Rights Protection."

${ }^{22}$ Hollenbach, "Borders and Duties to the Displaced: Ethical Perspectives on the Refugee Protection System."
} 
Fauzan, Helmi, Zulkifli Harza, Sri Oktavia | Capacity Building and Market Intervention for Refugees: A Study of Current and Future Direction towards Sustainable Refugee Management

than one million Syrian refugees in $2015^{23}$. The government also helps refugees with the direct and humanistic way through the integration process. These include supports on temporary accommodation and work opportunities. Although integration is a complex and multidimensional issue, it needs to combine all factors including economic, health, educational and social contexts, because refugees have a lack of understanding of diversity, experiences and knowledge ${ }^{24}$. The integration is also intended to bridge interaction with German citizens and neighborhoods in order for refugees to start a new life in Germany and to have smooth relation with local people.

In the Southeast Asia Nations (ASEAN) region, states also acted differently when receiving a large number of Rohingya's refugees from Myanmar in 2015 since there seems no comprehensive policy of refugees in the region. Indonesia, Malaysia, and Thailand have become three countries in the region that received Rohingya's refugees after having mass criticism internationally due to being refused to give them protection previously ${ }^{25}$. In Malaysia for example, the number of Rohingya refugees in 2018 has reached almost 115.000 people, and Malaysia has been a very famous country for Rohingya ${ }^{26}$. However, Rohingya's refugees are reluctant to claim their status as refugees under the UNHCR since it could limit their movement and work opportunity. Similarly, the Government does not allow them to have legal status or work permits in the country which creates difficulties for refugees to

\footnotetext{
${ }^{23}$ Neis, Meier, and Furukawazono, "Welcome City: Refugees in Three German Cities."

24 Robila, "Refugees and Social Integration in Europe."

25 Wake and Cheung, "Livelihood Strategies of Rohingya Refugees in Malaysia 'We Want to Live in Dignity.",

${ }^{26}$ UNHCR, "Figures at a Glance."
}

search for a job ${ }^{27}$. As a result, they tend to look for work informally in the Country from their colleagues who have been already settled in the Country. It is argued that the biggest barrier for Rohingya to find a job in Malaysia is the absence of an identity document such as a passport or the UNHCR status $^{28}$.

Thailand also received a large number of Rohingya refugees although the number has a slight decrease from 106.000 in 2015 to 99.000 in $2017^{29}$. The Government together with UNHCR has provided temporary accommodation for the refugees. Unfortunately, the Country has been perceived as a transit country and creates opportunities for people smuggling to bring more refugees into the country. The Government of Thailand has urged to investigate the role of people smuggling after the findings of hidden camps and mass graveyard in the Country in $2015^{30}$.

Indonesia as one of ASEAN states has also received Rohingya refugees since 2015 although in a small number compared to Malaysia and Thailand. The arrival of 1300 refugees from Myanmar and Bangladesh in the province of Aceh after being floated in the ocean on their journey to in 2015 , has constituted the number of refugees in the Country up to $7.827^{31}$. Those refugees are placed in temporary accommodation as well as in the Immigration Detention Center. Most of Rohingya's refugees transiting in Aceh Province are on their journey to Australia, although it is difficult to enter Australia due to a tight policy implemented. Moreover, Australia has decreased its

27 Jacobsen and Fratzke, "Building Livelihood Opportunities for Refugee Populations: Lessons from Past Practice."

28 Wake and Cheung, "Livelihood Strategies of Rohingya Refugees in Malaysia 'We Want to Live in Dignity.",

${ }^{29}$ UNHCR, "Figures at a Glance."

${ }^{30}$ UNHCR, "Asia Tenggara: Perpindahan Campuran Melalui Laut."

${ }^{31}$ UNHCR, "Indonesia Factsheet December 2016." 
Fauzan, Helmi, Zulkifli Harza, Sri Oktavia | Capacity Building and Market Intervention for Refugees: A Study of Current and Future Direction towards Sustainable Refugee Management

refugee placement from 600 to 400 refugees in $2016^{32}$.

The experience of Indonesia in dealing with a refugee issue has been started since forty years ago when a large number of Vietnamese refugees arrived in Galang Island in Batam due to the Indochina crisis in $1976{ }^{33}$. Known as boat people, those refugees were placed in temporary accommodation in Batam established by the UNHCR while waiting for determining status and being resettled to third countries. Indonesia was also perceived tolerant in managing refugees by providing education and health support and had received international attention through the development of the state ${ }^{34}$. After all the refugees had been successfully resettled and some returned back to their origin country, the camp was finally closed in 1990 and become a tourist attraction in the province.

Currently, Indonesia has issued the Presidential Regulation in 2016 on Handling Foreign Refugees where provinces and local districts and municipalities are required to provide basic living and temporary accommodation for refugees in cooperation with the UNHCR ${ }^{35}$. In this regulation, the State has given authorities to sub-national layers at provincial and district levels to get involved in managing refugees sustainably. Although Indonesia could not determine the status of Rohingya due to not being a party of the Refugee Convention, the Country applies a non-deportation and nonrefoulement status. As stated in Law 5 in 1998 in Foreign Relation, the Country prohibits deportation and returning back the

\footnotetext{
${ }^{32}$ Nethery, "Troubled Transit: Asylum Seekers Stuck in Indonesia, Written by Antje Missbach."

${ }^{33}$ Tan, "The Status of Asylum Seekers and Refugees in Indonesia."

${ }^{34}$ Panjaitan, "Hubungan Penanganan Manusia Perahu Vietnam Di Pulau Galang Terhadap Kemaritiman Indonesia."

${ }^{35}$ Missbach, Adiputera, and Prabandari, "Is Makassar a ' Sanctuary City '? Migration Governance in Indonesia After the "Local Turn .'"
}

refugees if there is a danger for them to return back to their origin country ${ }^{36}$.

Other than Indonesia, most ASEAN countries have not yet either ratified their Convention on Refugees in 1951 and its Protocol in 1967. From 10 members of ASEAN, only the Philippines and Cambodia, that have ratified their Convention on Refugees, while the rest are not signatory members including Indonesia, Singapore, Myanmar, Laos, Malaysia, Brunei Darussalam, Thailand and Vietnam ${ }^{37}$. Being not a signatory member of the convention means that the international protection for refugees is carried out by the UNHCR including determining the status of refugees $^{38}$. Even though most ASEAN countries are not able to manage the arrival of refugees, the Region has issued a human right declaration in line with international humanitarian law and human rights instruments, as a guide to international protection for refugees in the region ${ }^{39}$. The ASEAN human rights declaration also provides common interests of countries to respect, promote and protect the life of refugees, including their fundamental rights such as civil and political rights, economic, social and cultural rights ${ }^{40}$.

\section{The UNHCR refugee management}

The UNHCR has the responsibility to handle the refugee matters for countries that are not a signatory of the Refugee Convention 1951 and Its Protocol 1967. There are three procedures conducted by the UNHCR, including repatriation to the origin countries, local integration, and resettlement

\footnotetext{
36 Alunaza and Juani, "Kebijakan Pemerintah Indonesia Melalui Sekuritisasi Migarsi Pengungsi Rohingya Di Aceh Tahun 2012-2015."

37 Taylor, "Refugee Protection in the Asia Pacific Region."

38 JRSI, "Pengungsi Dan Pencari Suaka Di Indonesia."

39 UNHCR, A Guide to International Refugee

Protection and Building State Asylum System.

${ }^{40}$ UNHCR, “ASEAN Human Rights Declaration."
} 
Fauzan, Helmi, Zulkifli Harza, Sri Oktavia | Capacity Building and Market Intervention for Refugees: A Study of Current and Future Direction towards Sustainable Refugee Management

process. The first two options are likely impossible to implement due to the fact that repatriation to the origin country that still faces difficulty and persecution is strictly prohibited by the International Humanitarian Law as well as the national law which could be harmful to refugees to return. The most promising task by the UNHCR is then to resettle those refugees to third countries ${ }^{41}$. However, the process of the UNHCR to resettle refugees takes a considerable amount of time, which means that refugees are still staying in the neighborhood or transiting countries with no certainty for their future livelihood.

However, UNHCR also faces a challenge in the resettlement process due to reducing quotas from states. As shown in Figure 1, it is predicted that there are 1.4 million refugees who have been identified as refugees and ready for resettlement among nearly 20 million refugees. Unfortunately, the number of refugees who have been successfully resettled to the third countries were only 75.000 in 2018 and predicted around 90.000 in 2019 or less than $0.1 \%$ from the total population ${ }^{42}$. Furthermore, the number of receiving countries has shown a decrease to nearly $50 \%$ since 2016 while the number of global resettlement necessity has increased by $17 \%$. This condition creates further uncertainty for the future of the resettlement of refugees and requires them to stay longer in transiting countries.

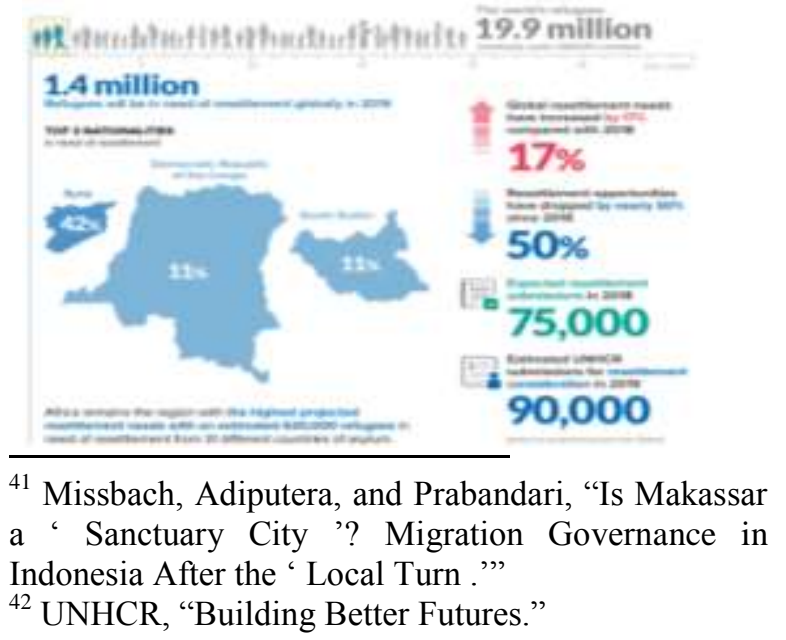

Figure 1: Global Refugee Resettlement (UNHCR, 2019b)

\section{The future direction towards refugee management}

As previously described, the current management of refugees by states and the UNHCR has faced a challenge and posed limitations. To overcome the refugee problem, it is important to have a partnership with different actors including private sectors in managing refugees sustainably as the future direction. In European countries, for example, the government has asked private sectors to become actively involved in a collaboration to formulate a migration policy $^{43}$. In the Asia Pacific, the involvement of business leaders is also viewed as an advantage through partnership in the Bali Process Declaration to overcome human trafficking, people smuggling, and other transnational crimes. Similarly, Australian example in collaborating with public and private sectors is also important to be taken into consideration, such as allowing migrants flow to business, providing returned incentives if the economy is slow, strong union monitoring to avoid cheap labor and other sympathy activities for migrants ${ }^{44}$. The new arrivals of refugees, therefore will likely be accepted generally if the field jobs and work opportunities are available for them to enter the labor market ${ }^{45}$.

In preparation for refugees to enter the labor market, it is a necessity for private sectors to develop skills and non-formal training for refugees through a capacity building program. It is believed that businesses can provide a contribution to refugee problems through training and skill

43 Menz, "The Neoliberalized State and Migration Control: The Rise of Private Actors in the Enforcement and Design of Migration Policy."

${ }^{44}$ Warshall, "Human Flow: Global Migrations."

45 Young, Loebach, and Korinek, "Building Walls or Opening Borders? Global Immigration Policy Attitudes across Economic, Cultural and Human Security Contexts is." 
Fauzan, Helmi, Zulkifli Harza, Sri Oktavia | Capacity Building and Market Intervention for Refugees: A Study of Current and Future Direction towards Sustainable Refugee Management

development for their future livelihood ${ }^{46}$. Moreover, it is the fact that large business entities tend to hire refugees to become their workers in supply chains for competitive advantages in the global market development ${ }^{47}$. In addition, large business sectors are also beneficial to recruit refugees appropriate for their company goals. This is because the skills and knowledge needed for a company have been identified that will be useful and productive for the company ${ }^{48}$.

In the global market development, it is also necessary to have a partnership with the International Labour Organization (ILO) to undertake a formal work possibility for refugees. This would be crucial to reduce human exploitation in the future particularly in the existence of human rights issues of refugees. The UNHCR, for instance, has collaborated with the ILO to provide a 5-year global education strategy in 2019-2022. The partnership is aimed to reduce the gap in education for refugees as well as to have the involvement of multi-stakeholders to develop refugee self-reliance. Primary sectors will be focused on non-formal and skill training of refugees ${ }^{49}$.

Previously, ILO and UNHCR have also had a partnership in the market and value chains implemented in many countries including South Africa, Costa Rica, Pakistan, Mexico, Egypt, and Zambia. The purpose of such collaboration is to increase protection for refugees and their households. Those collaborations will also enhance positive economic development in the host countries and communities through the push and pull factors. The former will have the initiative to focus more on the target group of refugees for skill development while the latter is

46 Horowitz, "Chobani CEO Hamdi Ulukaya Has a Message on Refugees Every Business Needs to Hear."

${ }^{47}$ Wang, "Bilateral Migration and Multinationals : On the Welfare Effects of Firm and Labor Mobility."

48 Sharma, "View: How Multinationals Can Help Solve Migration Debate."

${ }^{49}$ UNHCR, "Building Better Futures." related to the expansion of the market and increasing employability for refugees ${ }^{50}$. Such a partnership will also create future direction towards refugee protection due to the fact that refugees are part of human movement and thus, ensuring their certainty and livelihood opportunities will create sustainable refugee management.

The partnership has also been stated as the goal of 17 in the SDGs. The purpose of the partnership is to ensure that collaborating with global institutions will strengthen the achievement of SDGs in 2030 since the world has been more interconnected than before ${ }^{51}$. Through a partnership with private sectors, it is hoped that refugees will be able to develop their knowledge and skills for future work opportunities. Other global agendas including the importance of a partnership with relevant stakeholders are also mentioned in the Global Compact of migration and refugees. The Global Compact for Safe, Orderly and Regular Migration has specifically paid attention to migration matters. From 23 objectives of the Global Compact (GC), the objective of 23 in specific, has focused more on strengthening international cooperation as well as global partnership to promote safe, orderly and regular migration. These include bilateral, regional or multilateral partnership to propose appropriate solution to the mobility of people ${ }^{52}$.

Furthermore, at the end of 2018, the UN members have also agreed to establish the GC for Refugee as a framework to deal with the current situation of refugees. Both Compacts are not the binding obligation, rather it is a mutual understanding with no pressure to its members. Nevertheless, both Compacts of Migration and Refugee could

\footnotetext{
50 ILO, A Guide to Market-Based Livelihood Interventions for Refugees.

${ }^{51}$ UNDP, "Sustainable Development Goals."

${ }^{52}$ UNHCR, "Global Compact for Safe, Orderly and Regular Migration: Intergovernmentally Negotiated and Agreed Outcome."
} 
Fauzan, Helmi, Zulkifli Harza, Sri Oktavia | Capacity Building and Market Intervention for Refugees: A Study of Current and Future Direction towards Sustainable Refugee Management

be used as a guidance for countries to implement a safe and orderly movement for sustainable refugees in the future. The GC for Refugees, in particular, has stated the importance of partnership in dealing with the refugee issue in line with humanitarian principles. Specifically, the partnership in the $\mathrm{GC}$ for refugees includes the following: new institutional arrangements for the creation of business and financial instruments; supports for refugees, host, and transiting countries in employment and labor mobility enabling greater opportunities for private sector investment (UN General Assembly 2018). This is also in line with GC for refugee objectives including easing pressure in host countries, enhancing self-reliance of refugees, developing opportunities and access to developed states as well as providing a safe return of refugees in their home countries (Khasru 2016).

\section{Conclusion and Recommendation}

The influx of a large number of refugees since 2015 has attracted global attention. States that have authorities based on the Convention of Refugee in 1951 and Its Protocol in 1967 are reluctant to receive the new arrival of refugees into their territories. Meanwhile, the UNHCR has also faced a challenge in the resettlement process to third countries. On the one hand, the necessity of resettlement of refugees has increased while the resettlement quota from destination countries has been reduced, on the other hand. As a result, a lot of refugees have to wait uncertainly in transiting countries without livelihood opportunities in the future and this condition could lead to the possibility of human right violation.

Referring to the limitation of states and the UNHCR in managing refugees currently, it is a necessity to have an international collaboration as a future direction towards sustainable refugee management. Since refugee is a complex problem, it also needs different actors to get involved in refugee management including private sectors. Business entities are believed to be able to provide capacity building for refugees to prepare them entering market and labor opportunities in the future. Moreover, in the global development context, the partnership has also been acknowledged as one of the specific goals of SDGs in achieving the 2030 agenda. Other global initiatives including the Global Compact for Refugees also recognizes partnership as an important issue in providing self-reliance for refugees.

However, there are some limitations that should be addressed in the future research agenda. Firstly, this article views the role of states in managing refugees from security and social perspectives and dismisses the role of political decisions and intervention in the state management of refugees. In particular, political intervention is important in providing regulations and policies related to refugee management in practice, in which this article has not been yet acknowledged. Secondly, this paper has not yet conducted specific researches in delivering capacity building for refugees in order to prepare them entering the labor market. The types of capacity building in terms of formal or non-formal as well as duration and methods are not yet analyzed. Thirdly, it seems necessary for future research agenda to undertake the implementation of the transfer of knowledge in capacity building development programs in labor market opportunities. 
Fauzan, Helmi, Zulkifli Harza, Sri Oktavia | Capacity Building and Market Intervention for Refugees: A Study of Current and Future Direction towards Sustainable Refugee Management

\section{REFERENCES}

Alunaza, Hardi, and M. Kholit Juani. "Kebijakan Pemerintah Indonesia Melalui Sekuritisasi Migarsi Pengungsi Rohingya Di Aceh Tahun 2012-2015.” Indonesia Prespective 2, no. 1 (2017): 1-17.

Costello, Cathryn. "Refugees and (Other) Migrants: Will the Global Compacts Ensure Safe Flight and Onward Mobility for Refugees?" International Journal of Refugee Law 30, no. 4 (2019): 643-49. https://doi.org/10.1093/ijrl/eey060.

ESCAP. "UN Economic and Social Council: International Migration, the 2030 Agenda for Sustainable Development and the Global Compact for Safe, Orderly and Regular Migration" 00992, no. August (2017): 1-18.

Frelick, Bill, Ian M. Kysel, and Jennifer Podkul. "The Impact of Externalization of Migration Controls on the Rights of Asylum Seekers and Other Migrants." Journal on Migration and Human Security 4, no. 4 (2016): 190-220. https://doi.org/10.14240/jmhs.v4i4.68.

Grigonis, Simas. "EU in the Face of Migrant Crisis : Reasons for Ineffective Human Rights Protection.” International Comparative Jurisprudence 2, no. November 2016 (2017): 9398. https://doi.org/10.1016/j.icj.2017.01.003.

Hollenbach, David. "Borders and Duties to the Displaced: Ethical Perspectives on the Refugee Protection System.” Journal on Migration and Human Security 4, no. 3 (2016): 148-65. https://doi.org/10.14240/jmhs.v4i3.66.

Horowitz, Jake. "Chobani CEO Hamdi Ulukaya Has a Message on Refugees Every Business Needs to Hear," 2016. https://mic.com/articles/134406/chobani-ceo-hamdi-ulukaya-hasa-message-on-refugees-every-business-needs-to-hear\#.oGuDWawUC.

ICID. "TOWARDS SUSTAINABLE MIGRATION: Interventions in Countries of Origin." Italy, 2017.

ILO. A Guide to Market-Based Livelihood Interventions for Refugees. Edited by Nadja Nutz. Geneva: UNHCR, ILO, 2017.

IOM. "Migration in the 2030 Agenda." Switzerland, 2017.

Jacobsen, Karen, and Susan Fratzke. "Building Livelihood Opportunities for Refugee Populations: Lessons from Past Practice.” Washington, DC, 2016.

Jones, Reece, Corey Johnson, Wendy Brown, Gabriel Popescu, Polly Pallister-Wilkins, Alison Mountz, and Emily Gilbert. "Interventions on the State of Sovereignty at the Border." $\quad$ Political Geography 59 (2017): https://doi.org/10.1016/j.polgeo.2017.02.006.

JRSI. "Pengungsi Dan Pencari Suaka Di Indonesia." Jesuit Refugee Service Indonesia. Yogyakarta, www.jrs.or.id, 2013.

Mehan, Shalini. "From Care and Maintenance to Self-Reliance: Sustainable Business Model Connecting Malian Refugee Artisans to Swiss Markets Using Public-Private Partnerships." UNHCR New Issues in Refugee Research Working Paper Series No. 282, no. 282 (2016).

Menz, Georg. "The Neoliberalized State and Migration Control: The Rise of Private Actors in the Enforcement and Design of Migration Policy" 17, no. 3 (2009). https://doi.org/10.1080/09651560903457923.

Missbach, Antje, Yunizar Adiputera, and Atin Prabandari. “Is Makassar a ' Sanctuary City '? Migration Governance in Indonesia After the “Local Turn ”" 11 (2018): 199-216. 
Fauzan, Helmi, Zulkifli Harza, Sri Oktavia | Capacity Building and Market Intervention for Refugees: A Study of Current and Future Direction towards

Sustainable Refugee Management

Neis, Hans Joachim, Briana Meier, and Tomoki Furukawazono. "Welcome City: Refugees in Three German Cities." Urban Planning 3, no. 4 (2018): 101. https://doi.org/10.17645/up.v3i4.1668.

Nethery, Amy. "Troubled Transit: Asylum Seekers Stuck in Indonesia, Written by Antje Missbach." Asian Journal of Social Science 45, no. 1-2 (2017): 208-10. https://doi.org/10.1163/15685314-04501010.

ODI. "Migration and the 2030 Agenda for Sustainable Development," 2018.

Onwuegbuzie, Anthony, and Nancy Leech. "On Becoming a Pragmatic Researcher: The Importance of Combining Quantitative and Qualitative Research Methodologies." International Journal of Social Research Methodology: Theory and Practice 8, no. 5 (2005): 375-87. https://doi.org/10.1080/13645570500402447.

Panjaitan, Cok Deniro. "Hubungan Penanganan Manusia Perahu Vietnam Di Pulau Galang Terhadap Kemaritiman Indonesia.” ResearchGate, 2017. http://lontar.ui.ac.id/file?file=digital/137265-T Yani Indrastuti.pdf.

Robila, M. "Refugees and Social Integration in Europe." United Nations Department of Economic and Social Affairs (UNDESA) Division for Social Policy and Development United Nat, no. May (2018): 1-17.

RSO Bali Process. "Declaration of the Seventh Ministerial Conference of the Bali Process on People Smuggling, Trafficking in Persons and Related Transnational Crime (Bali Process)," 2018.

Sharma, Mihir. "View: How Multinationals Can Help Solve Migration Debate." Bloomberg, April 6 ,

2017. //economictimes.indiatimes.com/articleshow/58041570.cms?utm_source=contentofintere st\&utm_medium=text\&utm_campaign=cppst.

Sugiyono. Metode Penelitian Kombinasi (Mixed Methods). Bandung: Alfabeta, 2017.

Susetyo, Heru, Fitria, and Rozaq Asyhari. Rohingya: Stateless People and Nowhere To Go. Edited by Heru Susetyo, Fitria, and Rozaq Asyhari. Jakarta: Pusat Informasi dan Advokasi Rohingya Arakan (PIARA) dan Pusat Advokasi Hukum dan Hak Asasi Manusia Indonesia (PAHAM), 2016.

Tan, Nikolas Feith. "The Status of Asylum Seekers and Refugees in Indonesia." International Journal of Refugee Law 28, no. 3 (2016): 365-83. https://doi.org/10.1093/ijrl/eew045.

Taylor, Savitri. "Refugee Protection in the Asia Pacific Region." Accessed June 28, 2019. $\mathrm{http} / / / \mathrm{www}$.refugeelegalaidinformation.org/refugee-protection-asia-pacific-region.

UNDP. "Sustainable Development Goals." Undp, 2015, 24. https://doi.org/10.1017/CBO9781107415324.004.

UNHCR. A Guide to International Refugee Protection and Building State Asylum System. Handbook for Parlementarians, 2017.

$$
\text { "ASEAN Human }
$$

https://www.refworld.org/docid/50c9fea82.html.

Rights Declaration,"

2012. - "Asia Tenggara: Perpindahan Campuran Melalui Laut" 2, no. 1 (2015): 23-27.

. "Building Better Futures." In Global Appeal 2019 Update, 202-27. Switzerland, 2019.

"Figures at a Glance," 2019. https://www.unhcr.org/figures-at-a-glance.html.

. "Forced Displacement in 2017." Global Trends, no. 25 JUNE 2018 (2018): 76. https://doi.org/10.1080/09584939308719709. 
Fauzan, Helmi, Zulkifli Harza, Sri Oktavia | Capacity Building and Market Intervention for Refugees: A Study of Current and Future Direction towards

Sustainable Refugee Management

- "Global Appeal $2019 \quad$ Update." $\quad$ Switzerland, 2019. http://reporting.unhcr.org/sites/default/files/ga2019/pdf/Global_Appeal_2019_full_lowre s.pdf.

- "Global Compact for Safe, Orderly and Regular Migration: Intergovernmentally Negotiated and Agreed Outcome." Vol. 1949, 2018. https://refugeesmigrants.un.org/sites/default/files/180713_agreed_outcome_global_comp act_for_migration.pdf.

- "Indonesia Factsheet December 2016," no. December (2016): 1-3. http://www.unhcr.org/id/wp-content/uploads/sites/42/2017/05/Indonesia-Fact-SheetDecember-2016.pdf.

Wake, Caitlin, and Tania Cheung. "Livelihood Strategies of Rohingya Refugees in Malaysia 'We Want to Live in Dignity,"' no. June (2016): 1-43. http://www.odi.org/hpg.

Wang, Chun-kai. "Bilateral Migration and Multinationals : On the Welfare Effects of Firm and Labor Mobility," no. Aprilr (2014): 1-46.

Warshall, Peter. "Human Flow: Global Migrations." Whole Earth, 2002.

Weis, Paul. "The 1951 Refugee Convention: The Travaux Preparatoires Analysed with a Commentary." UN High Commissioner for Refugees (UNHCR), 1990, 1-272. https://doi.org/10.5771/0506-7286-1999-3-397.

Young, Yvette, Peter Loebach, and Kim Korinek. "Building Walls or Opening Borders? Global Immigration Policy Attitudes across Economic , Cultural and Human Security Contexts 누." Social Science Research 75, no. June (2018): 83-95. https://doi.org/10.1016/j.ssresearch.2018.06.006. 